\title{
Results and Elasticity of Gamification in Training and Development Processes
}

\author{
Siméia Azevedo Santos ${ }^{1}$ \\ Orcid: https://orcid.org/0000-0001-9815-390X
}

\author{
Leonardo Nelmi Trevisan ${ }^{2}$ \\ Orcid: https://orcid.org/0000-0002-0914-3679
}

Elza Fatima Rosa Veloso ${ }^{3}$

Orcid: https://orcid.org/0000-0002-9494-2108

\begin{abstract}
Gamification is the use of games elements in different contexts out of the games. It is a tool with potential application in several areas in management, like marketing and human resources, including training and development. Departing from this reference, this study has objective to identify the perception of efficiency and the measurable results in the gamification processes in training and development in a sample of the Brazilian market. This research is divided into two samples. The quantitative sample investigated the perception of efficiency of the professionals who already participated in the gamified training, the information was collected through an online form with Likert scale responses and treated with Minitab statistical software. The other sample was qualitative and sought to identify the perception of the professionals who developed the gamified training, and the results were submitted to the content analysis technique. The compiled results confirmed the presence of engagement and its influence on motivation as one of the advantage points for the application of gamification in training. It was also possible to find in these results the relevance of the design for the game / training interaction to work effectively. Among the trends of higher incidence found in this research are the possibility of associating gamification with virtual reality and augmented reality to enhance the experience lived by the player during training. As a secondary's incidents, but also relevant and congruent with market trends, are the incidents of concision with relevance, interaction, applicability and the digital trail, items present in the concept of learning in micro-moments.
\end{abstract}

Keywords: Gamification.Training.Development.Engagement.

\section{INTRODUCTION}

The last two decades have witnessed a rapid deployment of central human resources activities, making the area function responsibilities evolve to a more strategic level. The first evolution progressively added to human resources management procedures in the areas of labor and union relations, recruitment and selection, compensation and benefits, performance, quality of life, training and

\footnotetext{
${ }^{1}$ Professora Assistente na FIA Business School e na Saint Paul Escola de Negócios, Brasil. E-mail: sazevedotreinamentos@gmail.com

${ }^{2}$ Professor na Pontifícia Universidade Católica de São Paulo -PUC-SP, Brasil. E-mail: lntrevisan@pucsp.br

${ }^{3}$ FIA - Fundação Instituto de Administração, Brasil. E-mail: elzafrv@gmail.com
} 
development. In a more recent cycle, this evolution also reached computerization and the use of algorithms in the composition of the management of these subsystems of human resources, as approached by Posthumuset al. (2017).

One of the subsystems is the training and development area, which is an effort to improve the skills of the people applied in their work context, and which progressively brings improvement of performance to the organization. Training is an education process that externalizes the individual's potentialities, providing information to learn new knowledge and to develop skills and new skills for application in the professional context. It is also a process of short-term assimilation that aims to recycle knowledge, skills or attitudes directly related to the tasks performed at work (Marras, 2016).

According Dutra (2016), the learning process goes through different stages, with actions of different natures interacting synergistically among each other and allowing the individual to reach his personal development goals as well as contribution to the organization.

One of the pillars in the composition of a training process is the survey of needs and the selection of the method for its application that has adherence to the needs and the context, making possible to verify the advances and the points of improvement at the end of the training (Noe et al., 2005).

With the emergence of new responsibilities in human resources management, new trends have become prominent in business in general. Meeker (2019) pointed to a trend report made possible by the widespread use of the Internet, the speed of adopting disruptive technologies, the availability of the internet and computing in the cloud, and how these new technologies are changing the way communication, learning and the world of work in general.
In the Meeker report (2019), in the list of online services that had the most increase of subscription during the years 2017 and 2018, the service of Sony PlayStation's access to games was in fourth place, behind only the popularity champions of content in entertainment Netflix, Amazon and Spotfy.

In this context of increasing access to the use of new technologies, there are also new tools available, such as the increasing use of gamificationbased platforms for collaboration and sharing of information. The use of games in training and development is an issue addressed in the literature since the 1990s (Gramigna, 1994; Falcão, 2008), already approaching the theme of learning in a playful way, having a greater force at the time in face-toface, board games, or offline, when compared to the years after 2000 .

With the availability of technologies and their increasing cheapness and popularization, training possibilities with the use of gamified and computerized elements and through virtual reality also begin to be more widely used and listed among prominent trends for years to come, as defined in the Great Place To Work report ${ }^{4}$.

The projection that the market for digital games and serious games has been taking in Brazil in recent years is also notable, and in 2018 was published with the support of the Ministry of Culture, the II Census of the Brazilian Digital Games Industry. Among the companies participating in the census, $16.3 \%$ refers to the development of games used for corporate training purposes (Sakuda, Fortim, 2018).

According to PoyatosNeto (2015) and Mattar (2018), the term "gamification" originated in the 1980s, although the first documented uses of the term "gamification" appear only in 2008. However, only in the mid of 2010 the term was consolidated as a

${ }^{4}$ https://gptw.com.br/conteudo/ 
technical language and became widely adopted.

The classic, well-quoted definition by Deterdinget al. (2011), approaches gamification as "the use of game design elements in non-game contexts."Gamification consists of the application of mechanisms, aesthetics and reasoning used in games, outside its usual context, associated with entertainment, with the purpose of solving practical problems, arousing engagement and promoting knowledge.

By elements of games, we refer to well-designed rules, points, challenges of competition, collaboration, puzzles, scenarios, among other factors related to the mechanics of motivation, interaction and reward (McGonigal, 2011; Marczewski, 2017). The use of the process of gamification is not synonymous of the use of games, but of the use of elements and mechanics present in game design.

Activities of different sectors can be gamified, such as in children's or adult education, in administration, in marketing, applied for example in branding or sales to help relationship with a certain brand in tourism, as an example in programs of points that have seen discount on tickets offered by airlines, in the sciences, and in more diverse possibilities, activities and segments. Examples of papers in this line are presented by Mattar (2018), who also cites cases, already referenced in Meister (2013) and Vianna (2013), with applied examples of gamification aimed at the corporate and business area.

Studies about gamification focused on human resources is still recent in the market and in the literature and has the potential for growth in applicability research and its results.

The main objective of the present study is to identify the perception of efficiency and measurable results in the gamification process, as an increase of high relevance in training and development actions, from the contextualization of the relationship between training, development and tendencies in gamification.

\section{THEORETICAL FRAMEWORK}

\section{Training and development}

Authors who studied human resource management have been subdivided into three or four groups since the 1980s, with training and development being one of these areas, such as Tichy, Fombrun and Devana (1982). Fidelis and Banov (2006), define training as a process of qualification and supply of professional needs that prepares the person to perform specific tasks for the position he occupies. Marras (2016) conceptualizes training as a way to help the adaptations in the knowledge, skills and attitudes of the individual in relation to the job or position occupied.

In his studies, Swanson (2009) defines the area of training and development as a process of development and encouragement of proficiency in order to improve the performance of the organization, the work processes, the group and each worker, culminating beyond learning and performance, career development and leadership.

According to Gruman and Saks (2011), performance management in organizations is generally aimed at encouraging workers to achieve goals or objectives consistent with the organization's objectives. DeNisi and Pritchard (2006) argue that this incentive occurs mainly due to two related factors, namely, the increase in access to information for the worker's performance, such as identifying the requirements to achieve measurable results, feedbacks and goals in progress; and encourage worker behavior to achieve these goals through incentives.

The training in corporations, managed by human resources, is a process that can be planned by the company to facilitate the learning of the employees of the functions or competencies related to the performance of their work (Noe et al., 2005). These 
competencies include knowledge, skills, or behaviors that are elementary to performance that drives a successful performance. The learning that is generated by training can come through observing and experiencing doing together, and through interaction with other employees, and joint use of all these means is common.

As success metrics for evaluating a training module, we can use observation of increased productivity, improvement in quality of results, reduction of costs related to time and rework, optimization of efficiency, perception of change in behaviors, elevation of knowledge and awareness. It also leads to improved organizational climate and increased personal motivation according to the report published by McKinsey (2018).

In studies on the subject, training and development situations that were not effective when considered within the context of the organizational culture also have their own studies and are cited for example in Argyris (1986), which addresses the problems of actions in which the author names of 'defensive looping', with the training and development programs that appear for leadership, which even come in their purpose of developing new skills, but in practice the situations where one should put this knowledge into action simply does not happen, generating this ironic looping.

For the training, the concern is to execute with quality and efficiency the application of the modules that were planned, the factors influencing the quality of the program being according to Marras (2016): Didactics and technical preparation of the training disseminators; Logic of the module, which should show the learning proposal and its application in the daily work; The source of the resources used, which can be diversified, such as the expository activities, with lectures, with the use of slides, films and audios; or interactive activities, with activities such as workshops, case studies, simulations, interactive activities on the internet, computer or smartphone, or the use of games or activities with elements of games that bring an experience of the context addressed.

New technologies are changing faster than at other times in history, the way people live, how they relate and how they work, thereby also substantially altering the way companies operate and how they interact, both internally and in the environment external and with the society (Folan, Browne, 2005; Malone, 2006; Cardadoret al., 2016; Schwab, 2016; $\mathrm{ILO}^{5}, 2018$ ).

\section{Gamification}

Gamification through computerized elements becomes a resource that can be explored in training and development activities. The term "gamification" originated in the 1980s, when Essex University professor Richard Bartle used the term "to make something that is not a game in a game."

Marczewski (2017) also argues that the application of game elements in other contexts can be called gamification or game thinking design, which the author defines as application of mechanisms, philosophies and rules of games in different contexts. Werbach and Hunter (2012) defines gamification as "the use of game elements and game design techniques in contexts other than games".

According Brathwaite and Schreiber (2009), game design is the "process of creating the content and rules of a game", the process of creating goals that a player feels motivated to reach and rules that a player must follow as he makes making meaningful decisions in pursuit goals.

Zichermann and Linder (2013) argue that gamification can be defined as the inclusion of a mechanics, style, thinking

\footnotetext{
5 https://www.ilo.org/global/topics/future-of-work/lang--
} en/index.htm 
or game design techniques to involve people in problem solving.

McGonigal (2011) and Marczewski (2017) explain the elements of games referring to well-defined rules, scoring score, competition challenges, collaboration, puzzles, among other factors related to the mechanics of motivation, interaction and reward. The use of the gamification process is not synonymous of the use of games, but the use of elements and mechanics present in game design.

\section{Games, Gamified Elements and Player Profiles}

From Huizinga's (2000) survey on games and playability, it is possible to identify eight main characteristics common to all activities considered or classified as games. These are: voluntary participation; play as distraction; play as external to reality; with limits of space and time, with a defined goal; with clear rules; with feedback system; and with an end.

Gamification is a methodology based on the dynamics of games, and aims to use tools based on elements of games, such as involvement, engagement, use of rewards and awards, and feedback, for example. According to Penenberg (2015), gamification in the corporate context improves performance precisely because of factors such as the use of rewards that reinforce positives, and engagement. The objective of using this methodology is to use the reward and rewards strategy to stimulate the participant or player to achieve their goal, generating a sense of accomplishment, receiving continuous feedback, stimulating progress, and consequently progressing towards the ultimate goal, according to Marczewski (2017).

The proposal of the gamification activities, when applied to the training processes, is to provide learning with playful, natural and dynamic, aiming to stimulate problem solving skills, motivate the player or participant to continue to reach the next objectives, supported by the feedback received. (McGonigal, 2011, Adams, Dormans, 2012). A proposal of activity with the use of gamified tools is characterized by clear and well-defined objectives, which lead to the escalation of small achievements, which can be divided into specific moments and activities and with adaptive time, with advances evidenced through continuous feedback. The participation of the player must always be voluntary, with prior knowledge of the rules of the activity, just as it works in a game.

According McGonigal (2011) and Deterdinget al., (2011), the game contains rules that will generally represent challenges to be faced by the player to achieve the ultimate goal. The gamified task, by providing continuous feedback and rewarding small goal achievements in the player's performance, allows the player to have a clear view of their progress, as well as recognition through awards or badges, elements that combined bring to these activities characteristics of engagement similar to what is perceived in games. Both in the material environment and in the digital environment, it is important that the game has its clear message, its goals and its objective must be clearly understood by the player.

Tracking progress through welldefined task completion is another point that must be made very clear (Chandler, 2012, McGonigal, 2016). This element is linked to the developmental issue perceived by the player, or the individual participating in the training, and also to the feedback issue that is received at the end of each small task, at the end of a phase or grouping of tasks. The feedback process is also tied to receiving the rewards, either by the scoring level or by the chosen award method used by the environment. Also, the user interface, especially in digital environments, also needs to be contextappropriate to achieve the desired results.

In order to understand how the game and its elements work in interaction with the 
player - an essential aspect in the interplay between game and training expectations - it is important to highlight which are the main profiles of players, since each profile participates in the game for a purpose or a motivation main. One popular type of player proposal is the 'Bartle Test', also explored by the studies of Zichermann and Cunningham (2011). The four basic player profiles are the conquerors or achievers, the explorers, the socializers, and the predators or killers.

According to Yee (2006), Salen and Zimmerman (2012), although each player has a dominant profile characteristic, all types can coexist with aspects of the other profiles of lower dominance, depending on the context and type of the game with which the player is interacting at a certain moment. In his analysis, Yee (2006) adds three types of components that influence the motivation of the players, composed of goals, social context and immersion in the game environment.

Tracking progress through welldefined task completion is another point that must be made very clear (Chandler, 2012, McGonigal, 2016). This element is linked to the developmental issue perceived by the player, or the individual participating in the training, and also to the feedback issue that is received at the end of each small task, at the end of a phase or grouping of tasks. The feedback process is also tied to receiving the rewards, either by the scoring level or by the chosen award method used by the environment. Also, the user interface, especially in digital environments, also needs to be contextappropriate to achieve the desired results.

Game dynamics are composed of elements that support the user or player over the duration of the game. Included in the dynamics proposed by Werbach and Hunter (2012) are the narrative that keeps the game coherent and the emotions that the player experiences during the game; Mechanics are actions that can be performed, directing and engaging the player, serving as an element of transition between the player's experience and their interaction with the digital medium. Werbach and Hunter (2012) list as main mechanics the challenges, the rewards and the random elements; The components are elements that can be used in the interface of the game, such as defined goals, medals and avatars.

According to Marczewski (2017) and McGonigal (2011, 2016), the use of games may trigger some triggers for the player, especially regarding the mechanisms of motivation, emotion and behavior, due to the reactions generated by the activities of feedback that generate what these authors call engagement looping.

In the game environment, the unpredictability that in real life is viewed with tension, can take on a playful aspect and bring learning, exactly because the game environment represents safe space, away from real risks. According to Burke (2015), and Mullins and Sabherwal (2018), gamification involves people in an emotional context, and this is revealed as a powerful factor of engagement. Not forgetting the intrinsic motivation generated by the sense of autonomy, which progresses along with the domain of a certain topic, such as learning some subject addressed in a training.

Just as in a game, a tool has the essential characteristic of formulating clear and well-defined goals. The participation of the user must always be voluntary, with prior knowledge of the rules that will generally represent challenges to be faced by the player to achieve the goal. For Suits (2005) play is a voluntary attempt to overcome obstacles. According to McGonigal (2011), the presence of challenges requires the use of the player's creativity and skills to achieve the goal, which makes the task rewarding when solved. The game provides continuous feedback on performance in the activity, so that the player has a clear notion of their progress and is recognized by him, characteristics that, coordinated and combined, bring to the gamified activities similar engagement to that perceived in the 
users of games in relation tasks proposed by the games.

The authors Werbach and Hunter (2012) define six steps for a good implementation of gamification, the 6 D's of gamification. The sixsteps are:

- Define business objectives understand and make clear the target goal. In order to define the objectives, the process suggested by the authors is to list the objectives in order of priority and to justify them;

- Delineate target behaviors - defined the objectives and the reason why gamification will be used, it is necessary to delineate what is expected of the users, their activities and behaviors in the system or in the game;

- Describe your players - what the relationship that the game will have with the players, if they are employees, if they are customers, what may motivate them to continue in the tasks are items to be described in this step;

- Devise activity cycles - define activity cycles so that players remain interested in participating in and overcoming the next challenges proposed, thinking about the type of feedback that will be provided to players or users of the game, and how these users will be engaged by activity loop based on tripod motivation, action and feedback;

- Don't forget fun! - users must voluntarily participate in the game, and this should be fun in the right measure;

- Deploy the appropriate tools - to check if there are tools already defined or developed for the proposed gamification that is to be implemented, to verify the possible tools to be used with the best cost-benefit.

With these steps suggested by Werbach and Hunter (2012) developed in a wellstructured and well-linked way it is possible to develop a gamified process, but the authors do not guarantee that following these steps will be enough to succeed in the gamified process, if the design of the process as a whole makes sense in the context in question, if the elements are well designed, if the interaction with the game is satisfactory. As Chandler (2012), Adams, Dormans, (2012), Cherry (2012) and Alves (2015) insist, it is necessary to verify if the system interfaces are satisfactory, if the analysis of information transfer or, if knowledge also happens in a satisfactory way, to satisfy convincingly the objectives proposed by the gamification.

\section{New technologies and trends}

Advances in technology have provided more efficient ways of performing activities and have increasingly transformed society's behavior in many ways, as we have seen in trend reports such as Meerker's (2018) for example.

The II Brazilian Census of the Digital Games Industry (Sakuda, Fortim, 2018) showed that about $43 \%$ of all games produced in Brazil are designed to run on mobile devices or smartphones, $24 \%$ are designed for computers, $16 \%$ are developed for the web platform, $10 \%$ are already developed to be executed with the aid of augmented reality and virtual reality technologies, $5 \%$ are executed via consoles, and about $0.5 \%$ are developed for social networks.

In comparison with the data of the I Census of the Brazilian Industry of Digital Games published in 2016 by the same researchers Sakuda and Fortim (2018), there was an average numerical growth of $290 \%$ of games developed to be executed with the aid of virtual reality technology or augmented reality, not only for games of pure and simple fun, but also for games of training processes for industries and for services. Gamification developed in digital and virtual environments, with the help of technology, has also generated new and incremental experiences.

The use of virtual reality and augmented reality to increase the experience of a game in the form of training (for experiences in situations that represent 
a greater degree of danger or insalubrity), as discussed in experiments exposed by Xtreme VR (2018) and by Kelly (2017).

Augmented reality is technology that allows the virtual world to blend in with the real world, opening up a greater number of possibilities for interaction and a new dimension in how to perform a task. Augmented reality literally 'augments' the real world with digital information from the virtual world (Godoy, 2017). Godoy (2017) also highlight that interactions can bring emotions as well as innovation to lived experiences.

The advantage of augmented reality in relation to virtual reality is mainly the cost of technology, more accessible thanks to the use of smartphones associated with augmented reality glasses (Xtreme VR, 2018). The challenge of its use is the same as mentioned in the process of gamification by Werbach and Hunter (2012), to define the points and the objective of the training, so that the transfer of the knowledge one wishes to do happens in an aggregating and satisfactory way.

In this process of evolution, it is mandatory to verify that technology is a tool, not an end in itself. The technological advance, therefore, assists and enhances the results sought by the training programs in the most varied contexts, but must be inserted together with relevant content (Sousa; Rocha, 2019; Gattuloaet al., 2019).

Another trend that has become possible with the features implemented by the smartphone and tested in many models of online courses is the use of small moments to learn something relevant, a resource exploited in models created by Google with the Primer app, and the LIT platform that received digital maturity recognition among Brazilian companies in the McKinsey survey in 2018.

Develop information technology enabled feedback systems it is a way that looking for interaction and mediation capabilities that can be harnessed to support more focused and timely feedback.
According Webb and Ifenthaler (2018), the results of an effective feedback process will be good teaching focused on students' needs and students who understand or are coming to understand their own learning needs. This increased understanding is prerequisite for students to be able to self-regulate their learning and thus to achieve autonomy in learning.

Self-regulated learning is generally regarded as desirable for learning especially for online learning. There is evidence of improved performance in online learning correlating with some aspects of selfregulated learning. Furthermore, intelligent adaptive algorithms for personalized feedback also have been developed in informational ambiences, which collaborates in the context of self-regulated learning, that the participant shape their own rules of advancement in relation to their learning or their time and training.

\section{METHODOLOGICAL PROCEDURES}

This exploratory research intends to aid the systematization of information in the area (Selltiz, 1974), and is composed of two groups or steps, one qualitative and other quantitative. According to Richardson (2015), the preliminary stage of the methodology chosen for the application of the research is the structure of the project and the literature review, or bibliographic research, raised outlining the object of study. And, according to Selltiz (1974), regarding the more defined concepts and the significant link between the results, it can be inferred that the greater the contribution of the study in its conclusions.

As for mixed methods, their composition occurs through the combination of qualitative and quantitative approaches, composed to reduce possible biases. Also according to Richardson (2015), although there are ideological differences between the methods, there are three moments in which the data can be integrated: during the planning of the 
research, in the collection of data or at the time of analysis of the information.

The qualitative step was made with data collected from interviews with semistructured questions, performed with professionals who have already applied or participated in the development of one gamified training. The selection of this nonrandom sample was defined by the requirement that the interviewee work in companies that foster a specific area of training by gamification or because they have developed solutions with specific and recognized consulting support. The data has been interpreted by this research through content analysis according to the proposal of semantic categorization of Bardin (1995), highlighting the frequency with which certain characteristics of the content appear and not only the presence of a determined element but also the absence of a certain characteristic in the message excerpt. Following the guidelines of Bardin (1995), the analysis for the categories must follow patterns of homogeneity in the context units, be exclusive in their categories, be objective and different coders can achieve the same results, suitable and relevant to the content or context exposed.

The quantitative step was performed through a survey questionnaire applied in an online environment for professionals who have already participated in some gamification training, with option of answer in Likert format arranged from 1 to 10, and with analysis of information by means and variance standards processed in the Minitab statistical software. As proposed by Cooper and Schindler (2003), the research strategies draw an approach and method designed for research and its mode of communication, also according to Vergara (1998) and Creswell (2007).

Together, both steps of the research seek to compose an overview of the perception of gamified training, both by those who apply the training and those who receive the training.

As a counterpoint, Charmaz's (2009) grounded construction theory was also considered. The grounded theory methods favor the perception of data from a new perspective and exploration of ideas about data through analytical writing from the beginning, which through the method it is possible to conduct and organize data collection. The method is based on guidelines and systematics, although flexible to collect and analyze the data aiming at the construction of a theory based on the data itself, questioning the analytical understanding we can have about them.

\section{Results and Discussion}

The form for the quantitative research step was built using the Google forms online tool and received 56 valid responses, who said they had already participated in corporate training. The collected responses were stored in a spreadsheet automatically generated by the Google forms response manager, and for the treatment of the data, the statistical software Minitab version 18 was used. With the database transferred to the Minitab 18 software, the database of questions was normalized, assigning the scale from 0 to 100 for the answers. In this step questions, one to six were characterized as validator fields, personal data or grouping profile.

From this range of questions, we highlight question about motivation to forward: "When I start a gamification training, I feel motivated to continue until I move forward or finish the cycle of proposed tasks", represented in figure 1, and the question about feedback perception: "I realize that I have constant feedback on my advancement when I am on a gamified training", represented in figure 2.

The indicator that had the best index was the question about the perception of engagement by the participants, with 83.214 of average, who are mostly motivated to continue and advance in the training phase, despite the presence of an outlier. For the question about the perception of feedback, the average was 80,612, median 85,714, and standard 
deviation 22,535, which is the secondhighest number average between the range of questions in this step. This index also follows in the direction of Marczewski's
(2017) diagram on the feedback loop and on the advancement of the player or user in the game.

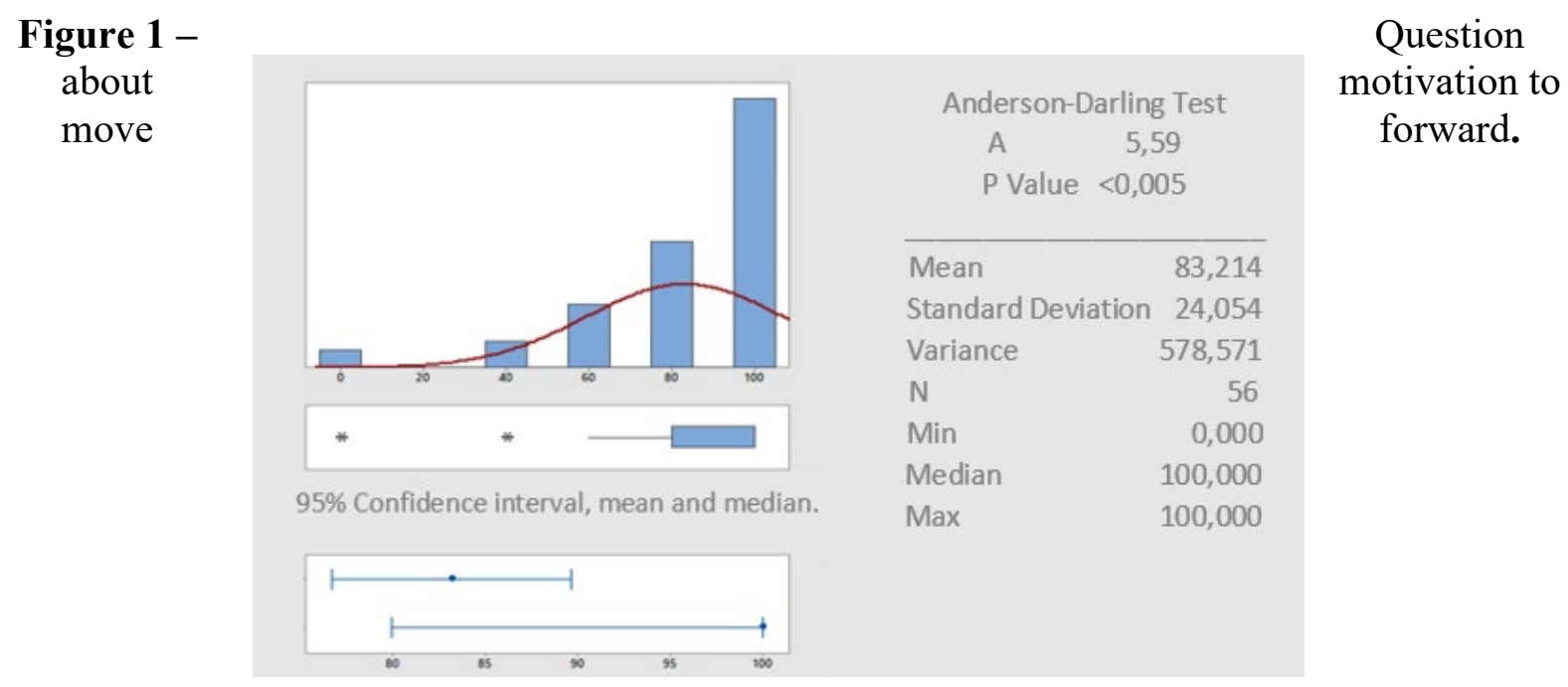

Source: Minitab research data, 2018.

Figure 2-Question about the feedback perception.

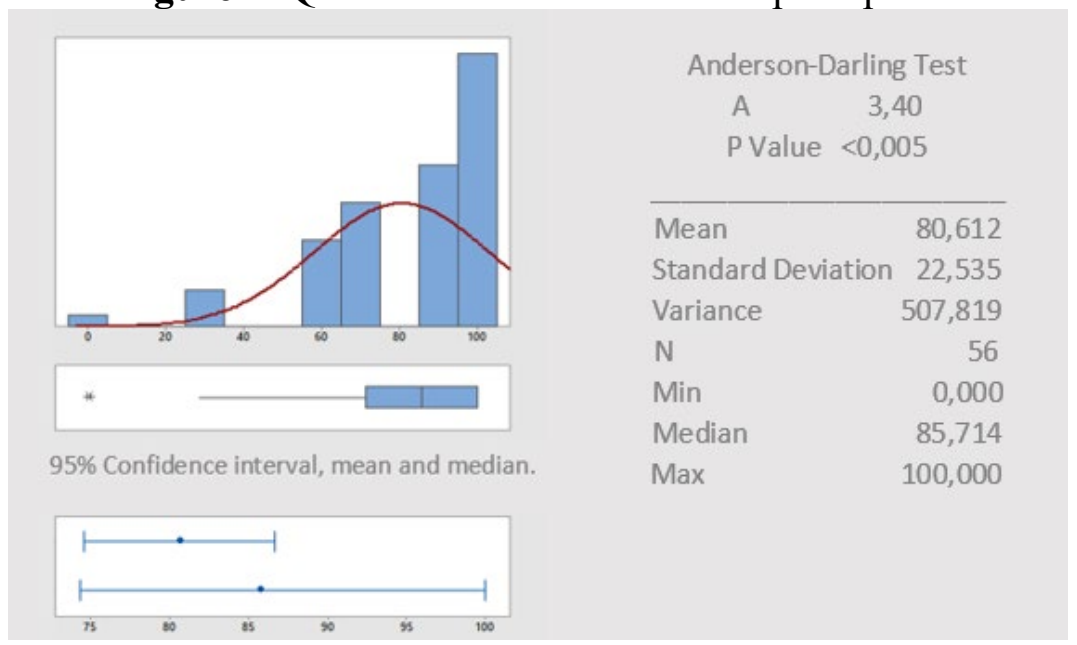

Source: Minitab research data, 2018.

The questions to construct the qualitative step of the research were elaborated in order to answer these objectives: to enumerate the main triggers of motivation of the gamification that can be explored in training and development; highlighting the main difficulties encountered in the application of gamification training; and describe characteristics that indicate a contribution to a skillful training and development.

The answers were given through an interview with ten professionals who have already participated in the construction and 
elaboration of gamification training. The contact with these professionals occurred initially through events in the area of human resources and technology, endorsed in most cases through contact via LinkedIn social network. All professionals interviewed have relevant professional experience in this area, work in some position in development projects and implementation of corporate training, with an average time of experience of five years.
Five questions had their content analyzed according to the analysis of content and categorization proposed by Bardin (1995), highlighting the frequency with which certain content characteristics arise. In this step, questions one to eight were characterized as validator fields, personal data or grouping profiles.

Table 1 - Highlights of qualitative and quantitative results

\begin{tabular}{|c|c|c|c|c|}
\hline Concept & $\begin{array}{l}\text { Qualitative } \\
\text { results } \\
\text { (percentual } \\
\text { appeared as a } \\
\text { categorized } \\
\text { code) }\end{array}$ & $\begin{array}{c}\text { Quantitative } \\
\text { results } \\
\text { (index on a scale } \\
\text { of } 0 \text { to } 100 \text { in } \\
\text { perception of } \\
\text { users) }\end{array}$ & Authors & Linked Concepts \\
\hline Engagement & $80 \%$ & 83.214 & $\begin{array}{c}\text { Alves } \\
(2015) \\
\text { McGonigal } \\
(2011)\end{array}$ & \\
\hline $\begin{array}{c}\text { Continuous } \\
\text { feedback } \\
\text { that } \\
\text { promote } \\
\text { engagement }\end{array}$ & \multicolumn{2}{|c|}{ bridge between codes } & $\begin{array}{l}\text { McGonigal } \\
\text { (2011) }\end{array}$ & $\begin{array}{c}\text { Accuracy of } \\
\text { information in a } \\
\text { shorter time, } \\
\text { promoting feedback } \\
\text { and creating greater } \\
\text { engagement. } \\
\text { Microlearning. }\end{array}$ \\
\hline Feedback & $30 \%$ & 80.612 & $\begin{array}{c}\text { Marczewski } \\
\text { (2017) }\end{array}$ & \\
\hline $\begin{array}{c}\text { Diversified } \\
\text { Strategy }\end{array}$ & $60 \%$ & & $\begin{array}{l}\text { Werbach } \\
\text { and Hunter } \\
(2012) \\
\text { Marras } \\
(2016)\end{array}$ & $\begin{array}{l}6 \text { D's for the } \\
\text { gamification; } \\
\text { Didactics and } \\
\text { technical preparation } \\
\text { of the training } \\
\text { disseminators. }\end{array}$ \\
\hline
\end{tabular}

Source: Research data, 2018.

Starting from a global analysis of the categories listed by the research, we can highlight the frequency that the code "engagement" appears as an answer to questions about factors that the interviewee liked more and about what he believes to be an advantageous aspect in training.
There is a link between engagement and the individual's intrinsic motivation, as can be seen in the excerpt of an interview: "it signals its progress and engages, and it is by intrinsic motivation."

According to Alves (2015) approach, this engagement is directly linked to the 
relevance of the content addressed to the users of the game, and the form used to promote learning.

This factor is directly linked to the next major item of research codes, the "design flaw" issue, and the strategy diversification, which is important to maintain attention and interest and achieve a satisfactory result with all player profiles, so its relevance and importance in appearing as a category in the analysis, as addressed by Zichermann and Cunningham (2011) in the main activities that interest each one of the four player profiles.

According to Werbach and Hunter (2012), one of the six elements of gamification is the fun and playful factor that exists in the game, but Werbach and Hunter (2012) also point out the importance of using fun in the right measure, without exaggeration, a factor that also coincides with the results found in the interviews.

Following the code list, the "trend" category was singled out by four of the respondents in question about the general perception of training, and addresses interesting points, alluding to the use of gamification as a tool to reach the attention of generating new aspects inspired by games and citing even new technologies that can be associated with the gamification process, such as virtual reality or augmented reality, which can be used not only for corporate executive training but for many technical trainings, heavy industry or pharmaceutical industry. Kelly (2017) addresses in his history and studies on the "forces that will change the world", the way that smartphone has leveled and popularized the use of technologies such as augmented reality, which generally require lighter technology compared to programs that run virtual reality.

Dynamics, mechanics, and components of game elements, as proposed by Werbach and Hunter (2012), also appear as categories in some responses: Dynamics of "interaction" with other players, response item on advantageous aspects, Mechanics of "collaboration", response's question about item you liked most in a gamified training; and mechanics of "feedback" on progression in the game, and Components, which are all the elements that can be used to build the game interface, represented in one of the answers found by the research by the category "diversified strategy" and also the category "ranking".

Some of the categories cited relate closely to the objectives listed in training and development theory, before they even connect with the goals of gamification in any given process, but actually linking purposes to a better outcome, such as the categories:

-"Clear strategy ", one of the points of attention raised by Marras (2016) and by Noe et al. (2005) is the list of steps to establish the need for training, making sure what items are covered by both the individual and the organization's needs list, the readiness level of the individual who will receive the training and the environment, and material to be used for this purpose, and also in the game, item evidenced in the six $6 \mathrm{D}$ 's for the gamification of Werbach and Hunter (2012).

-"Technology": one of the training strategies is the resources used in its application (Marras, 2016). In this category was mentioned the use of simulators and consoles as something that is used, but that has space and potential to evolve the quality.

-"Applicability": In the context of the training, if the person does not see value or relevance in the proposed action, there will be no relevant results. As stated by Dutra (2016), if the need is not latent or perceived by the user, there will be insufficient engagement in development actions.

-The category "concision with relevance" also demonstrates an aspect that encompasses the concern to present an efficient solution that is able to hold and 
maintain the attention of the user, and was cited as a category in the answers to question about what most contributed to the results.

Another interesting aspect of concision with relevance is that it can work information more accurately in shorter time frames, which is exactly the concept used in the theoretical example of Google Primer, and with the programs that are proposing activities in micro-moments, that is, taking advantage of 5 or 10 minutes to learn something or to make some activity. Concision with relevance walks along with applicability, as it becomes clear if the concept is straight to the point.

For questions such as metrification and evaluation, the discussion is more advanced not only in the measurement of results of the training but also in other areas of human resources, such as recruitment and selection through gamification processes, according to the list and interviews of the Brazilian HRTech's report of LIGA Ventures ${ }^{6}$.

The "digital trail" issue relates directly to this "metrics" point as well as to "data privacy", with the additional fact that the information left by everyone in the online virtual environment and in the cloud is a history and can be used for customizations, but can also invade privacy since the line is no longer so well delimited. Certainly, the issue of data privacy and authorization for its use is one of the global problems of modernity on the agenda for discussion in times of network data, process digitization and digital gamification. An early discussion in Brazilian legislation is the new LGPD General Data Protection Act, which will take effect, if there are no changes, in August 2020, but this is already a subject for another study.

The "mobility" category was mentioned by only one of the interviewees, but also highlights the possibilities brought by technology, specifically with the possibility of carrying out more activities remotely through the internet on a computer or a smartphone.

\section{CONCLUSION}

The results of this research aimed to identify the main central elements of gamification and its relation with training and development practices, from the compilation of the two steps of the research.

The high-frequency rate of the word "engagement" was the strongest indication of gamification agreement in training and development processes because the game helps to encourage this engagement on the part of the individual, and on the other, a training that hopes to achieve results must have its members engaged to reach the final purpose. The engagement is well quoted by professionals, and also have a good index of perception by the users, which strengthens the information.

Another interesting aspectwasthepresence of thecategories "playfulness" and "ludicity in therightmeasure", the first being addressed in its positive aspects, and the second, quoted negative in cases of exaggeration or in applications outside contexts.

The new forms of interaction brought into the theoretical framework, tools created from augmented reality and virtual reality, also appeared and were confirmed in the interviews through categories such as "trend" and "innovation".

The issue of technology insertion in this process also confirmed the facilities generated by the possibilities of large-scale application, metrics, mobility to access training through a game on a smartphone, but also brought insight into new issues, including "Data privacy" that gets

${ }^{6} \mathrm{https}: / /$ insights.liga.ventures/hrtechs/ 
registered on the network, and the question of history that people may end up leaving through their game logs, as quoted in the "digital trail" category.

AccordingtoMeeker's Internet trendsreport (2019), gamification continues to grow in trends, bringing interaction through gaming, video, voice, and text, has been used in online education and has also had significant growth in the problem- solving, stimulating recreation, collaboration and learning at the same time, as well as being pointed as a tool in the context of digitization.

Other categories such as "create habits", although it has been mentioned only once in the categorization, also make ties with both the habit-forming proposed in the learning loop of Herger (2014) and what is expected of a developmentprogram, such as proposedbyMarras (2016).

The results of the feedback process increased understanding for participants to be able to self-regulate their learning and thus to achieve autonomy in learning. Selfregulated learning in the context of gamut activities linked to the categories "concision with relevance", "applicability" and "metrics" allows the training participant to have more control and mastery over the time he has available for each task, against the tendency of learning in micro-moments, that is, in periods composed by half an hour or a quarter, for example.

The research sought to highlight what is applied in gamification of training processes with professionals who have already developed and applied training in this format successfully, but also listing difficulties and potential areas for improvement.

In the same way, we seek the opinion of professionals who have already been trained through this tool, so that each public could register their opinions and their perceptions for the composition of this scenario.
For games to be considered a viable tool, they must provide some means of testing and progress tracking and the testing must be recognizable within the context of the training they are attempting to impart.

As a contribution to the field, this research aimed to clarify understandings about the possibilities of gamification for the area of training and development, compiling information about the experiences of professionals working with the formulation or application of gamified training, and the perception of users who have already participated some gamified training. We also highlight the impacts of technological mediation on metrification and monitoring the training and development process.

The subject that studies gamification focused on the actions of human resources still has space and potential for growth in its actions and applicability researches and its results, for this reason, some of the suggestions for new studies are:

i. Continue to follow the growth of this market and the professional sectors that use gamification with more success, both in Brazil and in emerging markets;

ii. Understand more about the elements that can cause design flaws, and which ones are the most successful for the experiment,

iii. Investigate which common mistakes to avoid according to the type of training, the area of professional performance and the business segment, and

iv. Study the application of gamification in other areas of HR, such as recruitment, performance evaluation, or other business areas, such as marketing. 


\section{REFERENCES}

Adams, E.; Dormans, J, (2012). Game Mechanics: Advanced Game Design. California.

Alves, F. (2015). Gamification: como criar experiências de aprendizagem engajadoras - um guia completo do conceito àprática. São Paulo: DVS Editora.

Argyris, C. (1986). Reinforcing organizational defensive routines: anunintended humanre sources activity. HumanResource Management, V. 25, N. 4, p.541-555.

Bardin, L. (1995). Análise de conteúdo. Lisboa: Edições 70.

Brathwaite, B.; Schreiber, I. (2009). Challenges for game designers. Boston: Cengage Learning.

Burke, B. (2015). Gamificar: como a gamificação motiva as pessoas a fazerem coisas extraordinárias. São Paulo: DVS Editora.

Cardador, M. T.; Northcraft, G. B.; Whicher, J. (2016). A Theory of workgamification: somethingold, something new, somethingborrowed, something cool? Humanresource management review. 27. Set.P.353-365.

Chandler, H. M. (2012). Manual de produção de jogos digitais. Porto Alegre: Bookman.

Charmaz, K. (2009).A construção da teoria fundamentada: guia prático para análise qualitativa. Porto Alegre: Bookman.

Cherry, M. A. (2012). The gamification of work. Hofstra Law Review. V.40, n.4.

Cooper, D.; Schindler, P. (2003).Métodos de pesquisa emadministração. Porto Alegre: Bookman.

Creswell, J. (2007). Projeto de pesquisa:métodos qualitativo, quantitativo e misto. 2.ed. Porto Alegre: Artmed.
DeNisi., A. S.; Pritchard, R.D. (2006). Performance appraisal, performance management andimproving individual performance: a motivational framework. Management andOrganizationReview. 2. P.253277.

Deterding, S.; Sicart, M.; Nacke, L.; O’Hara, K.; Dixon, D. (2011). Gamification: Using game design elements in non-gaming contexts. Extended Abstracts on Human Factors in Computing Systems.New York: ACM Press, May.

Dutra, J. (2016).Gestão de pessoas: modelo, processos, tendências e perspectivas. São Paulo: Atlas.

Falcão, P. (2008). Criação e adaptação de jogos em T\&D. Rio de Janeiro: Qualitymark.

Fidelis, G. J.; Banov, M. R. (2006). Gestão de recursos humanos: tradicional e estratégica. São Paulo: EditoraÉrica.

Folan, P; Browne, J. (2005). A review of performance measurement: towards performance management. Computers in Industry. 56. P.663680.

Gattuloa, M. ;Scuratib, G. W.; Fiorentinoa, M.; Uvaa, A. E.; Ferrise, F.; Bordegonib, M. (2019). Towardsaugmented reality manuals for industry 4.0: A methodology. Roboticsand ComputerIntegrated Manufacturing Review, Elsevier, Vol. 56, p.276-286.

Gramigna, M. R. M. (1994). Jogos de empresa. São Paulo: Makron.

Gruman, J.A.; Saks, A.M. (2011). Performance management andemployeeengagement. HumanResourceManagementReview, 21. P.123136.

Godoy, F. (2017). Como utilizar a realidade aumentada para treinamentos. Acesso em 9 janeiro 2019 de: $<$ http://www.flexinterativa.com.br/blogflex/com o-realidade-virtual-realidade-aumentadatransformar-treinamentos-empresas-escolas>. 
Herger, M. (2014). Enterprise Gamification: Engaging people by letting they have fun. California, USA: CreateSpace Independent Publishing Platform, 2014.

Huizinga, J. (2000). Homo Ludens. São Paulo: Editora Perspectiva, Digital Source, $4^{\mathrm{a}} \mathrm{ed}$.

Kelly, K. (2017). Inevitável: as 12 forças tecnológicas que mudarão nosso mundo. São Paulo: HSM.

Malone, T. W. (2006).O futuro dos empregos: como o barateamento dos custos e a utilização das telecomunicações vão alterar a organização operacional, as condições de trabalho e a vida das pessoas nas empresas. Harvard Business School Press. M.Books: São Paulo.

Marczewski, A. (2017).Gamification design framework toolkit. Gamified UK.

Marras, J. P. (2016). Administração de Recursos Humanos, $15^{\text {a }}$ ed. São Paulo: Saraiva.

Mattar, J. (2018).Gamificação: conceito, críticas e aplicação a áreas de conhecimento. In: Ramos, D.; Cruz, M. Jogos digitais em contextos educacionais. Curitiba: Editora CRV.

McKinsey \& Co.; Box1824. Z Generarion, thetruegeneretion. 2018.

McGonigal, J. (2011).Reality is Broken: Why games makes us better and how they can change the world. New York: Penguim.

McGonigal, J. (2016).SuperBetter: The Power of Living Gamefully.New York: Penguim.

Meeker, M. (2018). Internet Trends Report. USA: Kleiner Perkins.

Meister, J. (2012). The Future of Work: How To Use Gamification For Talent Management. New Jersey: Forbes Magazine, 2012. Acesso em 17 maio de: $<$ https://www.forbes.com/sites/jeannemeister /2012/05/21/the-future-of-work-how-to-use- gamification-for-talentmanagement/\#7f492ffe98d3>.

Mullins, J; Sabherwal, R. (2018). Gamification: a cognitive-emotional view. Journal of Business Research, Elsevier.

Noe, R.; Hollenbeck, J.; Gerhart, B.; Wright, P. (2005). Human Resource Management:Gaining a Competitive Advantage. New York: McGrawHill.

Penenberg, A. L. (2015). Play atwork: how games inspire breakthrough thinking. Kindle version. New York: Portfolio Penguin.

Posthumus, J.; Santora, J.; Bozer, G. (2017). Howcan HR practitioners complementesearchalgorithms in recruitment of high potentials?Strategic HR Review. Vol. 16, n. 3, p.150-152.

Poyatos Neto, H. (2015). Gamificação: Engajando pessoas de maneira lúdica. São Paulo: FIAP.

Richardson, R. J. (2015).Pesquisa social: métodos e técnicas. São Paulo: Atlas.

Sakuda, L.O.; Fortim, I. (Orgs.). (2018). II Censo da Indústria Brasileira de Jogos Digitais. Ministério da Cultura: Brasília. Acesso em: 26 nov.

2018

de: $<$ http://www.tinyurl.com/censojogosdigitais $>$

Salen, K.; Zimmerman, E. (2012).Regras do Jogo: fundamentos do design de jogos, interação lúdica. São Paulo: Brucher.

Schwab, K. (2016). A quarta revolução industrial. Fórum Econômico mundial. São Paulo: Edipro.

Selltiz, C. (1974).Métodos de pesquisa nasrelaçõessociais. São Paulo: E.P.U.

Swanson,

R.

(2009).

Humanresourcedevelopmentquarterly: in thebeginning. WileyInterScience Online. Acesso em 07 outubro 2018 de: 
$<$ https://onlinelibrary.wiley.

com/doi/epdf/10.1002/hrdq.20002>.

Werbach, K; Hunter, D. (2012).Forthewin: how game

Suits, B. (2005). The Grasshopper: games, life and utopia. Ontario: Broadview Press.

thinkingcanrevolutionizeyourbusiness. Wharton Digital Press.

Tichy, N.; Fombrun, C. J.; Devanna, M. A. (1982). StrategicHumanResource Management. Sloan Management Review, 23, pp. 47-60.

Vergara, S. C. (1998). Projetos e relatórios de pesquisa em administração. São Paulo: Atlas.

Xtreme VR. (2018). Realidade Virtual. Vila Olímpia, São Paulo.

Yee, N. (2006). Motivations for play in online games. Cyber Psychology\&Behavior. V.9 n.6.

Zichermann, G.; Cunningham, C. (2011). Gamificationby design: implementing game

Vianna, Y. (2013).Gamification, Inc.: como reinventar empresas a partir de jogos. Rio de Janeiro: MJV.

Webb, M; Ifenthaler, D. (2018). Assessment as, for, and of Twenty-FirstCentury Learning UsingInformation Technology: An Overview. [J] Springer InternationalPublishing. mechanics in web and mobile apps. EUA: O'Reilly Media.

Zichermann, G.; Linder, J. (2013). The gamification Revolution:howleadersleverage game mechanicsto crush thecompetition. McGraw-Hill Europe.

\footnotetext{
${ }^{1}$ Siméia Azevedo Santos

Mestre em Administração pela Pontifícia Universidade Católica de São Paulo - PUC-SP

${ }^{2}$ Leonardo Nelmi Trevisan

Doutor em Ciência Política pela Universidade de São Paulo - USP

${ }^{3}$ Elza Fatima Rosa Veloso

Doutora em Administração pela Universidade de São Paulo - USP
} 